\title{
Deteksi Cemaran DNA Babi Dengan RT-PCR Pada Sosis Tanpa Logo Halal di Kabupaten Pandeglang
}

\section{Detection of Pig DNA Contamination With RT-PCR In Sosis Without Halal Labels From District Pandeglang}

\author{
Tuti Rostianti Maulani, Hadi Susilo, Marlinda Indriati, A.Suhaemi \\ Universitas Mathla'ul Anwar Banten \\ Jl. Raya Labuan KM 23 Kec. Saketi Kab.Pandeglang Banten \\ * tutirostianti@gmail.com
}

\begin{abstract}
Abstrak
Sosis merupakan produk olahan daging yang cukup digemari di masyarakat khususnya di Kabupaten Pandeglang Provinsi Banten. Pentingnya sertifikat halal atau adanya logo halal MUI (Majelis Ulama Indonesia) untuk produk olahan daging membuat masyarakat muslim yakin untukmengkonsumsinya. Tujuan dari penelitian ini adalah identifikasi cemaran DNA babi pada produk sosis yang beredar di 4 kecamatan di Wilayah Kabupaten Pandeglang tanpa logo halal MUI menggunakan RTPCR (Real Time- Polymerase Chain Reaction) dan Pork Detection Kit. Metode dalam penelitan ini diawali dengan menggunakan Pork Detection Kit untuk pengujian antigen babi sebagai kontrol positif dan daging sapi sebagai kontrol negatif yang akan digunakan untuk running RT- PCR. Hasil running $R T$ - PCR terhadap sampel DNA sosis di wilayah 4 (empat) kecamatan di Kabupaten Pandeglang (Majasari, Picung, Munjul, Cimanuk) tanpa label halal MUI menunjukkan trend DNA kontrol negatif pada kurva amplifaksi $R T$ - PCR. Hal ini teridentifikasi bahwa sampel DNA sosis tanpa label halal MUI di 4 kecamatan di Kabupaten Pandeglang tidak tercemar DNA babi
\end{abstract}

Kata kunci : DNA; Halal; Pork Detection Kit; RT- PCR; Sosis

\begin{abstract}
Sausage is a meat product processed that is popular food especially in Pandeglang, Banten Province. The importance of halal certificates or the existence of the MUI (Indonesian Ulama Council) halal logo for processed meat products makes Muslim people confident to consume them. The aim this research was to identify pig DNA contamination in sausage products in 4 subdistricts in Pandeglang without the MUI halal labels using RT-PCR (Real TimePolymerase Chain Reaction) and Pork Detection Kit. The method in this research begins with using the Pork Detection Kit for testing the pig antigen as a positive control and beef as a negative control which will be used for running RT-PCR. The results of running RT-PCR on sausage DNA samples in 4 (four) districts in Pandeglang (Majasari, Picung, Munjul, Cimanuk) showed a negative control DNA trend on the RT-PCR amplification curve. It was identified that the sausage DNA samples without MUI halal labels in 4 subdistricts in Pandeglang were not contaminated with pork DNA.
\end{abstract}

Keywords: DNA; Halal; Pork Detection Kit; RT-PCR; Sausage 


\section{PENDAHULUAN}

Indonesia adalah negara terbesar dengan penduduk mayoritas muslim di dunia. Jumlah penduduk Indonesia sekitar 269,6 juta jiwa (BPS 2020), dengan sekitar 87\% muslim mencapai 229,62 juta jiwa (Global Religius Future, 2020) merupakan pangsa pasar yang besar dalam penyediaan produk halal di Indonesia juga sangat bepengaruh terhadap gaya hidup dalam pemilihan produknya. Undangundang No. 33 Tahun 2014 tentang Jaminan Produk Halal (UU JPH) merupakan landasan perlindungan masyarakat dalam pemilihan produk halal. Dalam UU JPH Pasal 25 berisikan pelaku usaha yang telah memperoleh sertifikat halal wajib mencantumkan label halal terhadap produk yang telah mendapat sertifikat halal. Hal inilah yang melandaskan semua produk yang sudah dinyatakan halal oleh melalui fatwa MUI (Majelis Ulama Indonesia) wajib mencantumkan logo halalnya.

Salah satu produk yang sering terjadi pencemaran terhadap adanya babi adalah produk olahan daging. Sosis adalah produk olahan daging yang sangat disukai oleh masyarakat Indonesia terutama anak-anak. Produk sosis yang beredar di masyarakat saat ini adalah sosis bakar. Sosis berasal dari campuran daging yang dihaluskan dan diberi tepung atau pati dengan menggunakan tambahan bumbu dan bahan tambahan pangan (BTP), dimasukan ke dalam selongsong sosis kemudian diawetkan dengan cara pengasapan atau direbus (Herlina et al, 2015). Sosis merupakan salah satu jenis produk olahan daging yang dinilai paling rawan dari segi kehalalannya karena sering menggunakan bahan baku yang terkontaminasi spesies babi dalam pembuatannya, yaitu berupa daging babi, tetelan babi, hati babi, atau selongsong sosis yang terbuat dari gelatin maupun lemak babi. Banyak kejadian tentang adanya campuran daging babi dan daging sapi pada produk olahan baik bakso ataupun sosis. Pada tahun 2015 kejadian adanya produsen yang mencampurkan daging babi dan daging sapi pada produk olahan sosis (Suharjono, 2019).

Kabupaten Pandeglang adalah salah satu tempat di Provinsi Banten yang banyak sekali di pusat jajanannya menyediakan sosis sebagai jajanan yang juga disukai oleh masyarakatnya. Sosis yang dijajakan seringkali menyebabkan kecurigaan masyarakat akan kehalalannya karena seringkali sudah tidak ada kemasan dan kemasan sosis yang dijajakan juga tidak berlogo halal MUI. Upaya yang dilakukan dalam identifikasi adanya cemaran babi pada sosis yang beredar di pusat jajanan di 4 kecamatan Kabupaten Pandeglang belum dilakukan. Pada penelitian ini akan dilakukan identifikasi ada atau tidaknya cemaran DNA babi (Deoxyribonuclic Acid) babi menggunaan Real Time-Polymerase Chain Reaction (RTPCR). Salah satu metode yang cukup akurat dalam mendeteksi adanya cemaran DNA babi untuk mengetahui kehalalan produk olahan daging adalah menggunakan Real Time-PCR (Sari dan Wardani, 2015). Penelitian menggunakan RT-PCR sudah banyak dilakukan oleh peneliti sebelumnya, Balia (2014) menemukan adanya pemalsuan daging bakso dengan menggunakan daging babi menggunakan RT-PCR. Pada penelitian Cai (2012) menghitung jumlah kandungan DNA babi dan DNA sapi pada campuan gelatin menggunakan metode RT-PCR. Penelitian Harisah (2017) mengidentifikasi DNA Babi pada produk sosis dengan RT-PCR.

Manfaat dari penelitian ini adalah menjawab kecurigaan masyarakat dan menjawab keresahan masyarakat akan kehalalan produk sosis yang beredar di 
pusat jajanan di 4 kecamatan di wilayah Kabupaten Pandeglang. Sehingga dengan adanya jawaban dari hasil penelitian ini akan ada jawaban pasti bahwa sosis di pusat jajanan di 4 kecamatan di wilayah Kabupaten Pandeglang tidak tercemar DNA babi yang di haramkan dalam Al Qur'an. Tujuan dari penelitian ini adalah untuk mendeteksi ada atau tidaknya cemaran DNA Babi pada produk sosis yang beredar Kabupaten Pandeglang untuk menjawab kecurigaan masyarakat tentang produk sosis yang beredar di masyarakat.

\section{METODOLOGI}

Alat yang digunakan adalah RTM-PCR, Xema Test, timbangan analitik, Bunsen, pisau, pinset, tabung reaksi, gunting, tisu, plastik sampel, software PCR, Rotor-Gene $Q$, pipet, thermoblock shaker, laminar flow, sentrifuge, vortex, microtube, micropipet, ice block, heating block.

Bahan yang digunakan untuk penelitian adalah daging babi, sosis sapi, 4 sampel sosis untuk diolah menjadi sosis bakar tanpa label halal MUI diambil dari pusat jajanan yang tersebar di 4 wilayah Kabupaten Pandeglang, proteinase K, food lysis buffer, Chloroform dan Quantifast SYBR Green PCR Kit yang didalamnya ada: 2x Quantifast Mix, Rnase Free water dan primer.

\section{Pengumpulan sampel}

Pengumpulan sampel pada penelitian ini dilakukan, dengan metode accessible population yaitu populasi yang dapat dijangkau oleh peneliti (Millani et al. 2016). Sampel diambil di pusat jajanan di wilayah Kabupaten Pandeglang di 4 (empat) wilayah kecamatan yang terjangkau oleh peneliti yaitu : di Kecamatan Munjul, Kecamatan Picung, Kecamatan Cimanuk, Kecamatan Majasari, dari 4 (empat) kecamatan di wilayah Kabupaten Pandeglang peneliti hanya mengambil 1 (satu) sampel sosis untuk di uji Real Time PCR.

Pengambilan sampel pada penelitian ini menggunakan metode purposive sampling yaitu penentuan sampel dengan pertimbangan tertentu (Sugiyono 2005). Dalam penelitian ini sampel yang akan di uji Real Time PCR adalah produk olahan daging (sosis) yang tidak memiliki label halal MUI yang dijual oleh pedagang jajanan sosis bakar. Karena produk sosis yang memiliki label halal MUI pada kemasannya dianggap sudah terjamin kehalalannya.

\section{Isolasi DNA Sampel dan DNA Kontrol}

Isolasi DNA pada penelitian ini dilakukan terhadap daging babi, sosis sapi dan 10 sampel sosis bakar tanpa label halal MUI. Metode yang digunakan pada penelitian ini adalah metode ekstraksi DNA Fenol Chloroform yang umum digunakan didalam prosedur laboratorium (Kamaliah 2017). Tahap ekstraksi DNA dengan metode Fenol Chloroform terdiri dari tiga proses yaitu, proses lisi sel, purfikasi dan presipitasi. Sampel ditimbang sosis bakar tanpa label halal dan daging babi masingmasing sebanyak $200 \mathrm{mg}$ kemudian dimasukkan kedalam tube $2 \mathrm{ml}$. Proses lisis sel merupakan proses pertama ekstrasi DNA diawali dengan menghancurkan membran sel dengan cara menambahkan enzim proteinase $\mathrm{K} 2.5 \mu \mathrm{l}$ dan food lysis buffer $1 \mathrm{ml}$ untuk mengikat lipid sehingga membran sel rusak dan semu isi sel keluar dengan proses inkubasi menggunakan alat Thermo Shaker pada suhu $60^{\circ} \mathrm{C}$ selama 30 menit dengan kecepatan $1000 \mathrm{rpm}$, proses ini menyebabkan DNA bercampur dengan makromolekul sel lainnya, untuk mengurangi presipitasi sampel didinginkan pada suhu ruang lalu dimasukkan ke dalam ice block setelah inkubasi. 
Tahap kedua dari proses ekstrasi DNA adalah purifikasi pemurnian DNA dari makromolekul sel dilakukan dengan cara menambahkan Chloroform $500 \mu 1$ untuk mengikat makromolekul selain DNA seperti protein, lipid, dan karbohidrat. Kemudian disentrifugasi dengan kecepatan 2500 xg selama 5 menit (prinsip utama sentrifugasi adalah memisahkan substansi berdasarkan berat jenis molekul) pada tahap ini DNA dan air terpisah dari bahan organik lainnya setelah disentifugasi.

Tahap ketiga dari proses ekstrasi DNA adalah presipitasi, proses ini dilakukan untuk menarik air dari DNA. Dengan hati-hati lapisan yang bening dari tube yang telah melalui dua tahap sebelumnya dipindahkan dengan bantuan pipet tanpa menyentuh presipitasi yang terjadi di dasar tube, kemudian dimasukkan ke dalam tube $2 \mathrm{ml}$ yang berisi Chloroform $500 \mu \mathrm{l}$, lalu divortex selama 15 detik untuk menghomogenkan larutan dan disentrifuge dalam kecepatan $14.000 \mathrm{xg}$ selama 15 menit. Supernatan tersebut ditranfer ke dalam tube $2 \mathrm{ml}$ sebanyak $350 \mu \mathrm{l}$ untuk sampel sediaan proses Real Time PCR.

\section{Amplifikasi DNA dengan RT-PCR Pengujian Antigen Babi}

Pengujian antigen babi pada penelitian ini dilakukan untuk mengkonfirmasi kontrol positif pada daging babi dan kontrol negtif pada sosis sapi menggunkan metode Pork Detection Test dengan Xema Test yang selanjutnya akan digunakan untuk running Real Time PCR. Berikut prosesnya : Sampel ditimbang, daging babi dan daging sapi masing-masing sebanyak 200 mg. Dicairkan sampel dan siapkan. Test strip dipegang dengan memegang warna biru, celupkan ke dalam sampel sampai batas garis yang ditandai dengan tanda panah, tunggu selama 10-15 detik untuk memastikan cairan sampel menyerap ke dalam tes strip. Kemudian angkat tets strip dan letakan diatas permukaan yang rata dan steril, tunggu selama 5-10 menit hingga muncul garis berwarna dibagian tengah test strip. Hasil pengujian dibaca berdasarkan indikator (Tabel 1).

Tabel 1. Hasil Pengujian Dibaca Berdasarkan Indikator

\begin{tabular}{cll}
\hline No & \multicolumn{1}{c}{ Hasil } & \multicolumn{1}{c}{ Keterangan } \\
\hline 1 & Terlihat 2 garis merah & Positif mengandung babi \\
\hline 2 & Terlihat 1 garis merah & Negatif / tidak mengandung babi \\
\hline 3 & Tidak terlihat garis merah & Gagal / invalid \\
\hline
\end{tabular}

\section{Proses amplifikasi Real Time PCR}

Proses dilakukan dengan cara: PCR Mix dibuat dalam microtube $1.5 \mathrm{ml}$, sesuai dengan jumlah sampel pada Tabel 2. Pada amplifikasi PCR biasanya menggunakan 35-40 siklus (Muladno, 2010). Pada metode ini menggunakan 40 siklus (Tabel 2).

Tabel 2. Program Amplifikasi

\begin{tabular}{lccc}
\hline \multicolumn{1}{c}{ Tahap } & Waktu & Suhu & Siklus \\
\hline PCR initial activation enzim & $5 \mathrm{~min}$ & $95{ }^{\circ} \mathrm{C}$ & \\
Denaturasi & $10 \mathrm{~s}$ & $95{ }^{\circ} \mathrm{C}$ & 40 \\
Annaeling & $30 \mathrm{~s}$ & $95{ }^{\circ} \mathrm{C}$ & \\
\hline
\end{tabular}


Kemudian mesin PCR diprogram sesuai protocol software Rotorgene (Tabel 3). Instrumen RT PCR akan mengamplifikasi DNA secara otomatis dan memberikan hasil amplifikasi dalam bentuk kurva.

Tabel 3. Formulasi PCR Mix Quantifast SYBR Green PCR Kit

\begin{tabular}{cc}
\hline Komponen & Volume / \\
\hline 2x Quantifast Mix & $12.5 \mathrm{ul}$ microtube \\
\hline Primer Foward $(10 \mathrm{uM})$ & $0.75 \mathrm{ul}$ \\
\hline Primer Reverse $(10 \mathrm{uM})$ & $0.75 \mathrm{ul}$ \\
\hline Rnase Free water & $9 \mathrm{ul}$ \\
\hline Template DNA & $2 \mathrm{ul}$ \\
\hline Total volume reaksi & $25 \mathrm{ul}$ \\
\hline
\end{tabular}

\section{HASIL DAN PEMBAHASAN}

Pemilihan metode Real Time PCR pada penelitian ini dikarenakan pada Real Time PCR jumlah DNA yang diamplifikasi bisa langsung diamati secara Real Time sehingga tidak memerlukan analisis dengan elektroforesis gel untuk mengetahui hasil amplifikasi PCR.

\section{Pengujian Antigen Babi Dua Garis Merah}

Hasil sampel pada penelitian ini dilakukan pengujian antigen babi dengan metode Pork Detection Test pada daging babi dan sosis sapi menggunakan Xema Test, untuk mengkonfimasi kontrol positif pada daging babi dan kontrol negatif .

Pork Detection Kit merupakan metode uji cepat immunochromatograhic (lateral flow) yang digunakan untuk pengujian kualitatif atau semi-kuantitatif penentuan antigen daging babi. Antigen dari sampel akan terikat oleh antibodi yang sangat spesifik melekat pada warna partikel mikro yang kemudian mengalir ke garis tes dan bercampur dengan antibodi babi hingga membentuk garis berwarna yang menunjukkan hasil positif (Husni, 2017).

Hasil uji kontrol positif terhadap antigen babi dan kontrol negatif pada daging sapi dengan XEMA Test, dapat dilihat pada Tabel 4. Amanah (2014), mengatakan uji dengan metode Pork Detection Kit dan PCR efisien dan akurat.

Tabel 4. Hasil Uji Kontrol Positif Dan Kontrol Negatif Dengan XEMA Test.

No Jenis Sampel Hasil Keterangan Dokumentasi

$1 \begin{gathered}\text { Daging Babi } \\ \text { (Kontrol positif) }\end{gathered}$ Positif $\begin{gathered}\text { Telihat } 2 \\ \text { garis merah }\end{gathered}$




\section{Analisis Amplifikasi DNA Hasil Real Time PCR Berdasarkan Nilai Cycle Threshold}

Analisis amplifikasi DNA hasil real time pcr berdasarkan nilai cycle threshold pada penelitian ini dilakukan dengan melihat kenaikan kurva dan nilai Ct (cycle threshold) pada kurva amplifikasi. Ct adalah jumlah siklus sampel mulai terbaca yang menunjukkan awal mulainya fase pertumbuhan eksponensial, semakin rendah nilai Ct semakin tinggi jumlah DNA target sebaliknya semakin tinggi nilai Ct semakin rendah jumlah DNA target (Zilhadia et al., 2017). Hasil amplifikasi DNA menggunakan Real Time PCR pada sosis sampel terlihat pada Gambar 1.

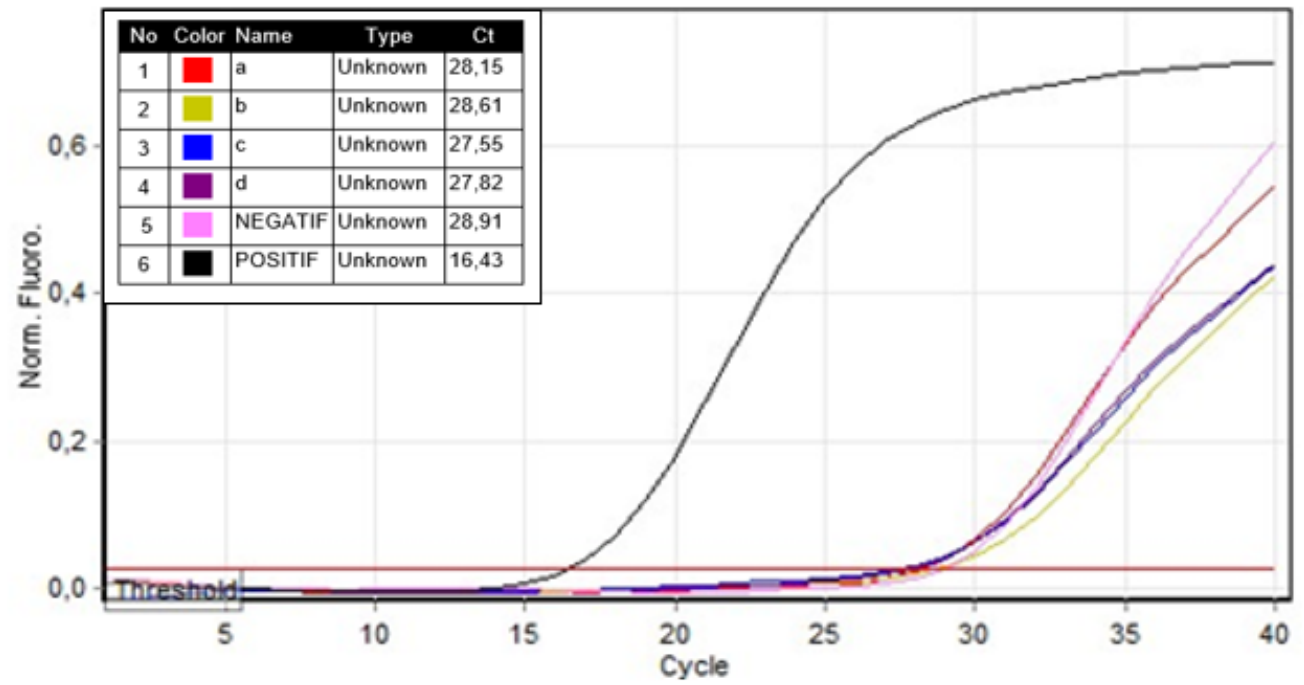

Gambar 1. Kurva Amplifikasi Sosis Di 4 Wilayah Kabupaten Pandeglang

Pada DNA 4 sampel sosis bakar tanpa label dari wilayah Kabupaten Pandeglang, dapat dilihat pada Tabel 5.

Tabel 5. Nilai Ct Hasil Amplifikasi DNA 4 Sampel Sosis Bakar Tanpa Label

\begin{tabular}{cccc}
\hline No & Asal Sampel & Kode Sampel & Nilai Ct \\
\hline 1 & Kecamatan Munjul & A & 28.15 \\
\hline 2 & Kecamatan Picung & B & 28.61 \\
\hline 3 & Kecamatan Cimanuk & C & 27.55 \\
\hline 4 & Kecamatan Majasari & D & 27.82 \\
\hline
\end{tabular}

Hasil amplifikasi DNA 4 sampel sosis bakar tanpa label halal dari 4 kecamatan di wilayah Kabupaten Pandeglang menghasilkan nilai Ct 27.55 - 28.61 yang mendekati nilai Ct DNA sosis sapi kontrol negatif dengan nilai Ct 28.91, artinya konsentrasi DNA yang teramplifikasi hasil running Real Time PCR pada DNA 4 sampel sosis tanpa label halal MUI dari 4 kecamatan di wilayah Kabupaten Pandeglang adalah rendah. Berdasarkan analisis hasil amplifikasi DNA yang dilihat dari nilai Ct memperlihatkan bahwa pada DNA sosis sapi kontrol negatif memiliki nilai Ct yang tinggi artinya konsentrasi DNA yang teramplifikasi hasil running Real Time PCR adalah rendah. Menurut Zilhadia et al., (2017) semakin rendah nilai Ct semakin tinggi jumlah DNA target, sebaliknya semakin tinggi nilai Ct semakin rendah jumlah DNA target. 


\section{Analisis Amplifikasi DNA Hasil Real Time PCR Berdasarkan Nilai Melting Temperatur Tm (Suhu Leleh)}

Kurva leleh merupakan kurva turunan dari hubungan antara fluoresensi dan suhu $(\mathrm{dF} / \mathrm{dT})$. Suhu Tm merupakan suhu saat 50\% amplikon DNA untai ganda terpisah menjadi untai tunggal, nilai Tm diketahui sebagai suhu pada saat munculnya puncak pada kurva Tm. Pada penelitian Rismaya (2018), analisis kurva leleh sangat disarankan untuk metode Real Time PCR karena dapat mengidentifikasi adanya amplifikasi nonspesifik maupun primer-dimer. Hasil amplifikasi DNA RTPCR berdasarkan nilai Tm terlihat pada Gambar 2.

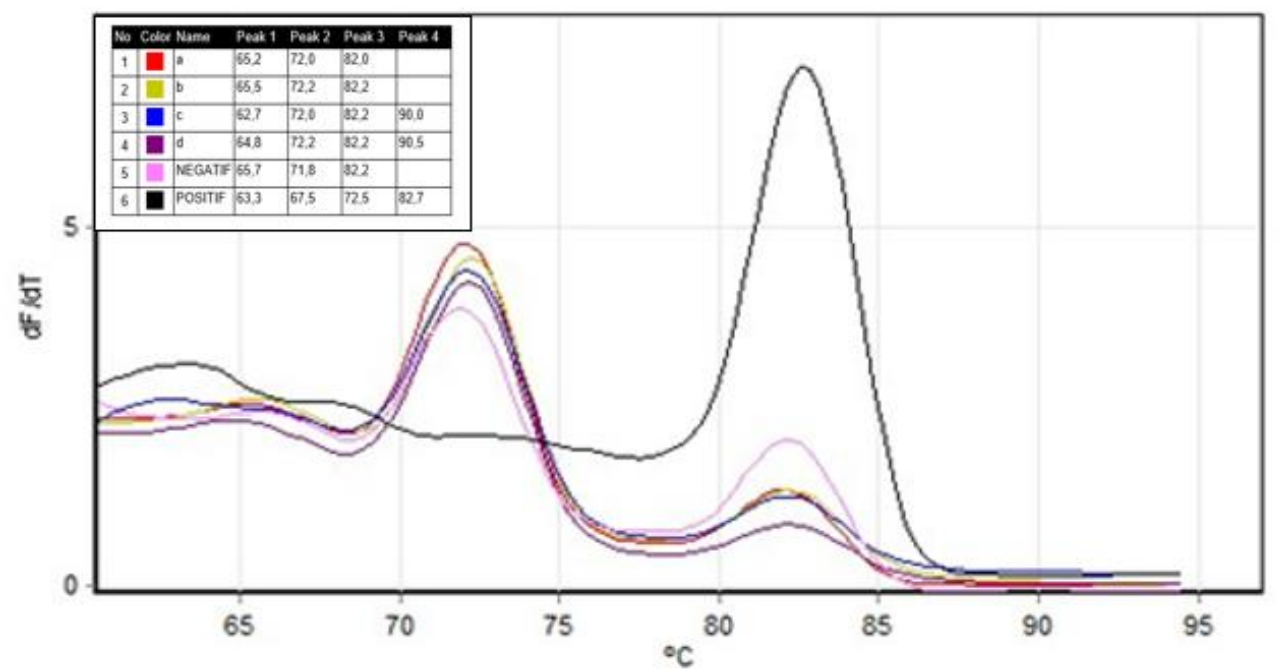

Gambar 2. Kurva Leleh (Melting Temperature Tm)

Analisis amplifikasi DNA hasil running Real Time PCR berdasarkan nilai melting temperatur Tm (suhu leleh), pada DNA daging babi kontrol positif menghasilkan satu amplikon dengan peak disuhu 82.7. Terbentuknya satu amplikon menunjukan DNA target teramplifikasi. Menurut Soares et al, (2017), mengatakan melting temperatur pada analisis Quantifast SYBR Green disuhu 80$8^{\circ} \mathrm{C}$. Nilai Tm pada DNA daging babi sebagai kontrol positif menunjukan hasil yang spesifik.

Pada DNA sosis sapi kontrol negatif telah terjadi dua amplikon dengan peak disuhu 72.0 dan 72.2. Pada DNA 4 sampel sosis tanpa label dari 4 kecamatan di wilayah Kabupaten Pandeglang, dapat dilihat pada Tabel 6.

Tabel 6. Suhu Peak Hasil Amplifikasi DNA 4 Sampel Sosis Bakar Tanpa Label

\begin{tabular}{cccc}
\hline No & Asal Sampel & Kode Sampel & Peak \\
\hline 1 & Kecamatan Munjul & a & 72.0 \\
\hline 2 & Kecamatan Picung & b & 72.2 \\
\hline 3 & Kecamatan Cimanuk & c & 72.0 \\
\hline 4 & Kecamatan Majasari & d & 72.2
\end{tabular}

Analisis amplifikasi DNA hasil running Real Time PCR berdasarkan nilai melting temperatur Tm (Suhu Leleh), pada DNA 4 sampel sosis tanpa label dari 4 kecamatan di wilayah Kabupaten Pandeglang, telah terjadi dua amplikon dengan 
Peak 1 disuhu 72.0 - 72.2, artinya DNA yang teramplifikasi hasil running Real Time PCR pada DNA 4 sampel sosis bakar tanpa label halal menunjukan memiliki titik leleh dibawah amplikon peak DNA daging babi.

\section{KESIMPULAN}

Sosis adalah jenis produk olahan pangan berbagan daging yang sangat disukai oleh masyarakat di Kabupaten Pandeglang. Sosis dalam olahan di bakar adalah jenis jajanan masyarakat yang paling disukai. Hasil deteksi adanya cemaran DNA Babi pada jajanan sosis di wilayah 4 Kecamatan di Kabupaten Pandeglang tidak terdeteksi adanya kontaminasi DNA Babi didalamnya. Hasil uji menggunakan Real Time - PCR pada sosis menunjukan hasil negatif adanya DNA babi pada sosis tersebut.

\section{UCAPAN TERIMA KASIH}

Terima kasih kami ucapkan atas pendaaan Hibah Penelitian Dosen Pemula Kementerian Pendidikan dan Kebuadayaan Direktorat Perguruan Tinggi Republik Indonesia Tahun Anggaran 2020.

\section{DAFTAR PUSTAKA}

Amanah, Z., 2014. Aplikasi Metode Porcine Detection Kit Dan Polymerase Chain Reaction (Simpleks Dan Multipleks Pcr) Untuk Deteksi DNA Sapi, Ayam Dan Babi Pada Bakso. Doctoral dissertation, Universitas Gadjah Mada.

Balia, R.L., Suryaningsih, L., Putranto, W.S., 2014. Pengujian Pemalsuan Bakso dengan Daging Babi Melalui Pendekatan Ensimatis dan Molekuler pada UKM di Kawasan Pendidikan Jatinangor Kabupaten Sumedang. Dharmakarya : Jurnal Aplikasi Ipteks untuk Masyarakat, Vol. 3 No. 2, pp. 70-72.

Cai, H., Gung, X., Scnalan, M.S., Ramatlapeng, D.H., Lively C.R., 2012. Real TimePCR Assays for Detection and Quantitation of Porcine and Bovine DNA in Gelatin Mixtures in Gelatin Capsule. Journal of food composition an analysis, 25: 83-87.

Fatimah, S., 2013. Deteksi Cemaran Daging Babi dalam Campuran Bakso Ayam dengan RealTime PCR dan Spektrofotometri FTIR. [Tesis], Fakultas Farmasi, Universitas Gadjah Mada, Yogyakarta.

Harisah, S.u., 2017. Analisis Cemaran Daging Babi pda Sosis Sapi Yang Beredar di Pasar Parung Menggunakan Metode Real Time PCR. Program Sudi Farmasi, Universitas Syarif Hidayatullah, Jakarta.

Herlina, H., Darmawan, I., Rusdianto, A.S., 2015. Penggunaan Tepung Glukomanan Umbi Gembili (Dioscorea esculenta L) Sebagai Bahan Tambahan Makanan pada Pengolahan Sosis Daging Ayam. Jurnal Agroteknologi. Jurusan Teknologi Hasil Pertanian. Fakultas Teknologi Pertanian. Universitas Jember.

Husni, P., Putriana, N. A., \& Wicaksono, I. A., 2017. Metode Deteksi Kandungan Babi dan Alkohol dalam Eksipien Farmasi dan Produk Obat untuk Menjamin Kehalalan Sediaan Obat. Majalah Farmasetika, 2(1), 1-7.

Millani, R. N., Suharti, N., \& Asterina, A., 2016. Uji Mikroorganisme pada Cabai (Capsicum annuum) Bakso yang Disajikan di Tempat Penjualan Bakso di Kecamatan Padang Timur. Jurnal Kesehatan Andalas, 5(3).

Muladno., 2010. Teknologi Rekayasa Genetik. Edisi ke 2 Bogor. IPB Press 
Kamaliah, K., 2017. Perbandingan Metode Ekstraksi DNA Phenol-Chloroform dan Kit Extraction pada Sapi Aceh dan Sapi Madura. Biotik: Jurnal Ilmiah Biologi Teknologi dan Kependidikan, 5(1), 60-65.

Sugiyono. 2005. Memahami Penelitian Kuantitatif. Bandung, Alfabeta

Suharjono., 2019. Daging Sapi dan Daging Babi Beredar di Pasar Gunung Kidul. SindoNews. Jawa Tengan

Soares, S., Amaral, J. S., Oliveira, M. B. P., Mafra, I., 2013. A SYBR Green RealTime PCR Assay to Detect and Quantify Pork Meat in Processed Poultry Meat Products. Meat Science, 94(1), 115-120.

Undang-Undang Republik Indonesia Nomor 33 Tahun 2014., 2018. Tentang Jaminan Produk Halal (Lembaga Republik Indonesia Tahun 2014 Nomor 295 dan Tambahan Lembaga Republik Indonesia Nomor 5604).

Zilhadia, Z., Izzah, A. N., Betha, O. S., 2017. Perbandingan Metode SYBR Green dan Hydrolysis Probe dalam Analisis DNA Gelatin Sapi dan Gelatin Babi Menggunakan Real Time Polymerase Chain Reaction. Jurnal Sains Farmasi \& Klinis, 4(1), 16-23. 